Open Access at : http://jurnal.umt.ac.id/index.php/replik/index

\title{
TINJAUAN YURIDIS ATAS TINDAK PIDANA KORUPSI DALAM PRAKTEK DI INDONESIA
}

\author{
Sumarni Alam \\ Fakultas Hukum Universitas Muhammadiyah Tangerang
}

\begin{abstract}
Abstrak
Kerusakan yang timbul akibat korupsi itu sudah sangat parah, sudah sangat keterlaluan. Korupsi tidak saja merugikan keuangan negara, tetapi juga telah merusak moral bangsa ini, menimbulkan kebodohan bangsa ini. Budaya korupsi telah menjadi seperti darah daging dalam kehidupan masyarakat negeri ini. Dalam setiap tindakan, dalam setiap perbuatan masyarakat yang berhubungan dengan instansi pemerintah, atau sebaliknya, tanpa terkecuali, terjadi praktek korupsi.

Korupsi benar-benar telah menjadi kejahatan yang sangat luar biasa, karena pebuatan korupsi itu terbukti telah mengakibatkan kesengsaraan terhadap rakyat Indonesia, telah menghapus kesejahteraan yang harusnya dinikmati oleh mereka, telah merampas hak-hak sosial mereka, bahkan dalam kasus-kasus tertentu telah merampas pula nyawa manusia.

Permasalahan yang dibahas dan dikaji dalam tulisan ini adalah bagaimana penyebab yang mendorong orang untuk melakukan perbuatan korupsi. Bagaimana upaya baik dari pemerintah maupun dari masyarakat dalam mengambil langkahlangkah dalam pemberantasan korupsi dan bagaimana bentuk pembaharuan kebijakan yang harus dilakukan Komisi Pemberantasan Korupsi (KPK) dalam pencegahan dan pemberantasan korupsi. Penulisan ini diharapkan dapat menjadi bahan masukan dan sumbangan pemikiran atau bahan pengembangan ilmu hukum khususnya di bidang hukum pidana.

Penulisan ini menunjukkan bahwa korupsi merupakan penyelewengan atau penggelapan (uang negara atau perusahaan) dan sebagainya untuk keuntungan pribadi atau orang lain serta selalu mengandung unsur "penyelewengan" atau
\end{abstract}


ketidakjujuran. Dan korupsi akan berdampak pada masyarakat luas serta akan merugikan masyarakat umum dan negara. Di Indonesia, korupsi identik dengan tindakan buruk yang dilakukan oleh aparatur birokrasi serta orang-orang yang berkompeten dengan birokrasi. Korupsi dapat bersumber dari kelemahan-kelemahan yang terdapat pada sistem politik dan sistem administrasi negara dengan birokrasi sebagai perangkat pokoknya.

Penerapan hukum juga merupakan penyebab lain meluasnya korupsi. Seperti halnya delik-delik hukum yang lain, delik hukum yang menyangkut korupsi di Indonesia masih begitu rentan terhadap terhadap upaya pejabat-pejabat tertentu untuk membelokkan hukum menurut kepentingannya.

Kata Kunci : Tinjauan yuridis atas tindak pidana korupsi.

\section{PENDAHULUAN}

Hampir dua abad yang lalu, Lord Acton (John Emerich Edward Dalberg Acton) dalam suratnya kepada Bishop Mandell Chreighton menulis sebuah ungkapan yang menghubungkan antara korupsi ${ }^{1}$ dengan kekuasaan, yakni : "Power tends to corroupt, and absolute power corroupts absolutely" (kekuasaan cenderung korup dan kekuasaan absolut cenderung korup absolut). Sejalan dengan Lord Acton, Prof. Miriam Budiardjo menisir dictum Lord Acton dan menyatakan bahwa, “orang yang memiliki kekuasaan cenderung untuk menyalahgunakannya. Orang yang memiliki kekuasaan absolut, sudah pasti akan menyalahgunakannya”. ${ }^{2}$

Selama ini korupsi lebih banyak dimaklumi oleh berbagai pihak daripada memberantasnya, padahal tindak pidana korupsi adalah salah satu jenis kejahatan yang dapat menyentuh berbagai kepentingan yang menyangkut hak asasi, ideologi negara, perekonomian, keuangan negara, moral bangsa, dan sebagainya, yang merupakan perilaku jahat yang cenderung sulit untuk ditanggulangi. Sulitnya

${ }^{1}$ Secara historis, korupsi berasal dari bahasa latin, Corruptio, dimana ia memiliki kata kerja Compere yang bermakna busuk, rusak, menggoyahkan, memutar balik atau menyogok. Menurut Undang-undang Nomor 31 Tahun 1999 Tentang Pemberantasan Tindak Pidana Korupsi mendefinisikan tentang pengerertian Korupsi kedalam Pasal 2 ayat (1), yaitu "Setiap orang yang secara melawan hukum melakukan perbuatan memperkaya diri sendiri atau orang lain atau suatu korporasi yang dapat merugikan keuangan negara atau perekonomian negara ....."

${ }^{2}$ Miriam Budiardjo, Dasar-dasar Ilmu Politik, Jakarta, 1977, hlm.99 
penanggulangan tindak pidana korupsi terlihat dari banyak diputus bebasnya terdakwa kasus tindak pidana korupsi atau minimnya pidana yang ditanggung oleh terdakwa yang tidak sebanding dengan apa yang dilakukannya. Hal ini sangat merugikan negara dan menghambat pembangunan bangsa. Jika ini terjadi secara terus menerus dalam waktu yang lama, maka dapat meniadakan rasa keadilan dan rasa kepercayaan atas hukum dan peraturan perundang-undangan oleh warga negara. Perasaan tersebut memang telah terlihat semakin lama semakin menipis dan dapat dibuktikan dari banyaknya masyarakat yang ingin melakukan aksi main hakim sendiri kepada pelaku tindak pidana di dalam kehidupan masyarakat dengan mengatasnamakan keadilan yang tidak dapat dicapai oleh hukum, peraturan perundang-undangan, dan juga para penegak hukum di Indonesia.

Hubungan korupsi dan kekuasaan juga pernah diungkap oleh seorang ahli dalam hukum pidana yang juga ahli dalam pemberantasan korupsi, Prof.Dr. Romli Atmasasmita, SH, LL.M, bahwa "Korupsi di Indonesia sudah merupakan virus flu yang menyebar ke seluruh tubuh pemerintahan, sehingga sejak tahun 1980-an langkah-langkah pemberantasannya pun masih tersendat-sendat sampai kini. Korupsi berkaitan pula dengan kekuasaan, karena dengan kekuasaan itu, penguasa dapat menyalahgunakan kekuasaannya itu untuk kepentingan pribadi, keluarga, maupun kroninya. Korupsi selalu bermula dan berkembang di sektor publik dengan buktibukti yang nyata, bahwa dengan kekuasaan itulah penguasa dapat menekan atau memeras para pencari kadilan atau mereka yang memerlukan jasa dari pemerintah". 3

Korupsi telah dianggap sebagai tindakan yang biasa dengan dalih "sudah sesuai prosedur". Koruptor tidak lagi memiliki rasa malu dan takut, sebaliknya mereka memamerkan hasil koruspsinya secara demonstratif. ${ }^{4}$ Politisi tidak lagi mengabdi pada konstituennya. Partai politik bukannya dijadikan wadah untuk memperjuangkan kepentingan rakyat banyak, melainkan menjadi ajang untuk mengeruk harta dan ambisi pribadi. ${ }^{5}$

Lebih memprihatinkan lagi adalah terjadinya perampasan dan pengurasan keuangan negara yang dilakukan secara kolektif oleh kalangan anggota legislatif

\footnotetext{
${ }^{3}$ Romli Atma Sasmita. Sekitar Masalah Korupsi Aspek Nasional dan Aspek Internasional, Bandung, 2004, hlm.1

${ }_{5}^{4}$ Soetanto Soephiady. Gerakan Indonesia Patut, Jakarta, 2005, hlm.2.

5 ibid
} 
dengan dalih studi banding, THR, uang pesangon dan lain sebagainya diluar batas kewajaran. Bentuk perampasan dan pengurasan keuangan negara demikian terjadi hampir di seluruh wilayah tanah air. Hal itu merupakan cerminan rendahnya moralitas dan rasa malu, sehingga yang menonjol adalah sikap kerakusan dan "aji mumpung”. Persoalanya adalah, dapatkan korupsi diberantas? Tidak ada jawaban lain kalau kita ingin maju, adalah korupsi harus diberantas. Jika kita tidak berhasil memberantas korupsi, atau paling tidak mengurangi sampai pada titik nadi yang paling rendah, maka jangan harap negara ini akan mampu mengejar ketertinggalannya dibandingkan dengan negara lain untuk menjadi sebuah negara yang maju. Karena korupsi membawa dampak negatif yang cukup luas dan dapat membawa ke jurang kehancuran.

Dalam Undang-Undang Komisi Pembetantasan Korupsi (KPK), tindak pidana korupsi adalah kejahatan luar biasa yang menimbulkan dampak yang sangat luar biasa pula bagi kehidupan nasional maupun internasional. Seorang terpidana korupsi pasti diancam pidana yang sangat berat atas tindak pidana mereka.

\section{PEMBAHASAN}

\section{A. Analisis Atas Tindak Pidana Korupsi di Indonesia}

\section{Pengertian Korupsi}

\section{a. Definisi Yuridis}

Dalam Undang-undang Nomor 31 Tahun 1999, pengertian koupsi yaitu setiap orang yang dengan sengaja melawan hukum untuk melakukan perbuatan dengan tujuan memperkaya diri sendiri atau orang lain atau korporasi yang mengakibatkan kerugian keuangan negara atau perekonomian negara.

\section{b. Menurut para ahli}

Menurut Mubyarto, pengertian korupsi adalah suatu masalah poltik lebih dari pada ekonomi yang menyentuh keabsahan (legitimasi) pemerintah di mata generasi muda, kaum elit terdidik dan para pegawai pada umumnya. Akibat yang ditimbulkan dari korupsi ini ialah berkurangnya dukungan pada pemerintah dari kelompok elit di tingkat provinsi dan kabupaten. Pengertian korupsi yang diungkapkan Mubyarto yaitu menyoroti korupsi dari segi politik dan ekonomi. 
Syeh Hussin Alatas mengemukakan pengertian korupsi, menurut beliau, korupsi ialah subordasi kepentingan umum dibawah kepentingan pribadi yang mencakup pelanggaran norma, tugas dan kesejahteraan umum, yang dilakukan dengan kerahasiaan, pengkhianatan, penipuan dan kemasabodohan akan akibat yang diderita oleh masyarakat.

Dari pengertian korupsi yang dipaparkan diatas, maka dapat disimpulkan bahwa pegertian Korupsi buruk seperti penggelapan uang, penerimaan uang sogok, dan lain sebagainya untuk memperkaya diri sendiri atau orang lain atau korporasi yang mengakibatkan kerugian keuangan pada negara.

\section{Orang Melakukan Perbuatan Korupsi}

Tentang kausa atau sebab orang melakukan perbuatan korupsi di Indonesia, pelbagai pendapat telah dilontarkan. Ditambah pengalamanpengalaman selama ini, kita dapat membuat asumsi atau hipotesis, misalnya sebagai berikut :

\section{a. Kuranya gaji atau pendapatan Pegawai Negeri dengan kebutuhan} yang semakin hari smakin meningkat.

Mengenai masalahnya kurangnya gaji atau pendapatan pegawai negeri di Indonesia telah dikupas oleh B. Sudarso yang menyatakan antara lain : "Pada umumnya orang menghubung-hubungkan suburnya korupsi sebab yang paling gampang dihubungkan, misalnya kurangnya gaji pejabat-pejabat, buruknya ekonomi, mental pejabat yang kurang baik, administrasi dan manajemen yang kacau yang menghasilkan adanya prosedur yang beliku-liku, dan sebagainya”. Kurangnya gaji bukanlah pula faktor yang menentukan. Orang-orang yang berkecukupan banyak yang melakukan korupsi. Prosedur yang berliku-liku bukanlah pula yang perlu ditonjolkan, karena korupsi juga meluas di bagian-bagian yang sederhana, di kelurahan, di kantor pengusaha-pengusaha yang kecil, di kereta api, di loket-loket penjual karcis kebun binatang, dan sebagainya”. 
Namun demikian, kurangnya gaji dan pendapatan pegawai negeri memang faktor yang paling menonjol dalam arti merata dan meluasnya di Indonesia.

\section{b. Latar belakang kebudayaan atau kultur Indonesia yang} merupakan sumber atau sebab meluasnya korupsi

Soedarto yang menunjuk beberapa penyebab dari korupsi, selanjutnya menguraikan panjang lebar tentang latar belakang kultur ini. Antara lain dikatakan sebagai berikut: "Dalam hubungan meluasnya korupsi di Indonesia, apabila miliu itu ditinjau lebih lanjut, yang perlu diselidiperlu diselidiki tentunya bukan kekhususan miliu orang satu per satu, melainkan yang secara umum meliput, dirasakan dan mempengaruhi kita semua orang Indonesia”.

Dengan demikian, mungkin kita bisa menemukan sebab-sebab masyarakat kita dapat menelurkan korupsi sebagai way of life dari banyak orang, mengapa korupsi itu secara diam-diam ditolereer, bukan oleh penguasa, tetapi oleh masyarakat sendiri. Kalau masyarakat umum mempunyai semangat anti korupsi seperti para mahasiswa pada waktu melakukan demonstrasi anti korupsi, maka korupsi akan sungguh-sungguh tidak akan dikenal.

c. Manajemen yang kurang baik dan kontrol yang kurang efektif dan efisien

Terkenal ucapan Profesor Soemitro almarhum yang dikutip oleh media cetak bahwa kebocoran mencapai 30\% dari anggaran. Ternyata usaha pendidikan dan pelatihan seperti P4 dan SESPA tidak mempan bukan saja untuk memberantas korupsi, tetapi juga untuk menguranginya. Korupsi semakin meningkat dari tahun ke tahun. Bahkan seorang widyaiswara di suatu Pusdiklat mengatakan bahwa pada tanggal 20 Mei 2002, bahwa sesungguhnya 50\% anggaran Pusdiklat dimakan oleh penyelenggara.

\section{d. Sebab korupsi ialah modernisasi}

Huntington menulis sebagai berikut : "Korupsi terdapat dalam masyarakat, tetapi korupsi lebih umum dalam masyarakat yang satu daripada yang lain, dan dalam masyarakat yang sedang tumbuh 
korupsi lebih umum dalam suatu periode yang satu dari yang lain. Bukti-bukti dari sana-sini menunjukkan bahwa luas perkembangan korupsi berkaitan dengan modernisasi sosial dan ekonomi yang cepat".

Modernisasi merangsang korupsi, karena perubahan-perubahan yang diakibatkannya dalam bidang kegiaan sistem politik. Modernisasi terutama di negara-negara yang memulai modernisasi lebih kemudian, memperbesar kekuasaan pemerintahan dan melipat-gandakan kegiatankegiatan yang diatur oleh peraturan-peraturan pemerintah.

\section{Upaya dan langkah-langkah pemerintah dan masyarakat dalam pemberantasan Korupsi}

Berbagai upaya telah dilakukan pemerintah untuk melakukan pemberantasan korupsi. Bahkan upaya pemberantasan korupsi itu, sudah dimulai sejak tahun 1950 dibawah pimpinan Jaksa Agung Suprapto, dan berlanjut pada tahun 1960-an dengan pembentukan Tim Pemberantasan Korupsi dibawah pimpinan Jenderal A.H. Nasution. Namun tim-tim pemberantasan korupsi tersebut kemudian dibubarkan.

Pada masa-masa Orde Baru, pemerintah menerbitkan Undang-Undang Nomor 3 Tahun 1971 tentang Pemberantasan Tindak Pidana Korupsi, diikuti dengan pembentukan Tim Operasi Khusus (Opsus) yang kemudian berganti nama menjadi Komando Operasi Pemulihan Keamanan dan Ketertiban (Kopkamtib), yang salah satu tugasnya ialah melakukan pemberantasan korupsi. Tetapi, tim-tim khusus itu kemudian "tiarap", menghilang untuk kemudian tidak terdengar lagi.

Harapan untuk memberantas korupsi muncul kembali setelah berakhirnya pemerintahan Orde Baru. Tetapi perubahan Undang-Undang Nomor 3 Tahun 1999 belum juga membuat korupsi hapus atau setidak-tidaknya berkurang, walaupun sesungguhnya ancaman hukuman terhadap pelaku korupsi sudah semakin diperberat. Oleh karena itu, Undang-undang Nomor 3 tahun 1999 tentang Pemberantasan Tindak Pidana Korupsi tersebut diperbaharui pula dengan Undang-undang Nomor 20 Tahun 2001. 
Bahayanya, walaupun telah berkali-kali Undang-undang tentang Pemberantasan Tindak Pidana Korupsi itu dirobah dan diperbaharui, termasuk dengan membentuk lembaga pemberantas tindak pidana korupsi melalui Undang-Undang Nomor 30 Tahun 2002 Tentang Komisi Pemberantasan Tindak Pidana Korupsi (KPK), tidaklah membuat surut nyali para koruptor untuk tetap melakukan korupsi.

Tidak tanggung-tanggung, dibentuk pula pengadilan khusus yang tugasnya melulu hanya mengadili perkara-perkara korupsi. Sebuah "gugustugas" besar yang seharusnya dapat diandalkan untuk menumpas korupsi yang sudah merajalela, bahkan dianggap sebagai kejahatan yang luar biasa, tetapi korupsi tetap berlangsung.

Sesungguhnya Undang-undang Nomor 31 Tahun 1999 yang memperbaiki beberapa ketentuan Undang-Undang Nomor 3 Tahun 1971 yang kemudian diperbaharui dan dirobah pula melalui Undang-Undang Nomor 20 Tahun 2001, telah cukup baik dan memadai untuk melakukan pemberantasan korupsi, sebab kedua undang-undang yang terbit belakangan ini telah merobah dan memperbaiki Undang-undang Nomor 3 Tahun 1971.

Perubahan dan perbaikan Undang-undang Nomor 31 tahun 1999 melalui Undang-Undang Nomor 20 Tahun 2001 seharusnya menambah daya "gempur" aparat penegak hukum untuk memberantas korupsi. Undang-undang ini menyebutkan secara langsung unsur-unsur yang terdapat dalam Kitab Undang-Undang Hukum Pidana (KUHP) yang sebelumnya tidak disebutkan secara langsung dalam Undang-Undang Nomor 31 Tahun 1999. Dengan adanya perubahan tersebut, akan memudahkan pemilihan terhadap materi hukum serta memberikan kejelasan terhadap obyek yang diatur oleh undangundang tersebut.

Saldi Isra menulis (Kompas, 5/2/2007), percaya atau tidak, di negeri ini, hukum tidak saja sebagai alat rekayasa sosial (law as a toll of social engineering), tetapi juga merupakan alat rekayasa untuk melakukan korupsi (law as a tool of corruption engineering). Buktinya, menurut Saldi Isra, adalah Peraturan Pemerintah Nomor 37 Tahun 2006 tentang Kedudukan Protokoler dan Keuangan Pimpinan dan Anggota DPRD. 
Kehadiran PP Nomor 37 Tahun 2006 tersebut bisa menjelaskan bahwa hukum merupakan alat rekayasa untuk melakukan korupsi. Sebagai produk hukum, dari pembentukannya, PP tersebut amat sentralistik dan oligarkis. Sementara itu, secara substansi PP Nomor 37 Tahun 2006 merupakan kehendak sepihak elite guna membenarkannya memperkaya diri dengan mengabaikan prinsip-prinsip hukum.

Dengan kata lain, bahwa upaya-upaya yang dapat dilakukan dalam memberantas korupsi antara lain :

\section{a. Strategi Pemberantasan Korupsi}

Guner Mirdal berpendapat bahwa jalan untuk memberantas korupsi ialah sebagai berikut :

1) Menaikkan gaji pegawai rendah (dan menengah);

2) Menaikkan moral pegawai tinggi; dan

3) Legalisasi pemungutan liar menjadi pendapatan resmi atau legal.

Sudah jelas bahwa kalangan elite kekuasaan harus memberi keteladanan bagi yang dibawah. Untuk mencegah korupsi besar-besaran, bagi pejabat yang menduduki jabatan yang rawan korupsi seperti bidang pelayanan masyarakat, pendapatan negara, penegakan hukum, dan pembuat kebijakan harus didaftar kekayaannya sebelum menjabat jabatannya sehingga mudah diperiksa pertambahan kekayaannya dibandingkan dengan pendapatan yang resmi.

Artinya, pegawai negeri atau pejabat yang tidak dapat membuktikan kekayaannya yang tidak seimbang dengan pendapatannya yang resmi dapat digugat langsung secara perdata oleh penuntut umum berdasarkan perbuatan melanggar hukum. Dengan demikian, harus ada sistem pendaftaran kekayaan pejabat sebelum dan sesudah menjabat, sehingga dapat dihitung pertambahan kekayaan itu.

Penuntutan pidana hanya mempunyai berfungsi sebagai obat yang terakhir. Jelas korupsi tidak akan terberantas hanya dengan penjatuhan pidana yang berat saja, tanpa suatu prevensi yang lebih efektif. 


\section{b. Upaya Pemberantasan Korupsi Seiring Kemajuan Teknologi dan}

\section{Komunikasi}

Dalam pemberantasan korupsi terkandung makna penindakan dan pencegahan korupsi, serta ruang untuk peran serta masyarakat yang seharusnya dapat lebih ditingkatkan dengan adanya perbaikan akses masyarakat terhadap informasi. Teknologi informasi dapat dimanfaatkan untuk perbaikan pelayanan publik sebagai salah satu cara melakukan pencegahan korupsi. Sedangkan di sisi penindakan (tanpa bermaksud mengesampingkan pro dan kontra yang terjadi) undangundang memberi ruang bagi para penegak hukum yaitu Kepolisian, Kejaksaan, dan Komisi Pemberantasan Korupsi untuk mendapatkan dan menggunakan informasi elektronik guna memperkuat pembuktian kasus korupsi.

\section{c. Menimbang Keseriusan Pemerintah dalam Pemberantasan Korupsi}

Di negeri ini, korupsi agaknya telah menjadi penyakit akut yang sulit untuk diberantas. Bertahun-tahun di bawah pemerintahan yang korup, menjadikan penyebaran korupsi semakin meluas dan sistemik. Korupsi yang meluas dapat dengan gampang kita jumpai pada hampir seluruh kantor pelayanan publik. Korupsi menjadi bagian dari sistem pengelolaan negara. Celakanya, korupsi kerap melibatkan petinggipetinggi negeri ini.

Dari sisi hukum, aparat penegak hukum juga tampak letoy ketika berhadapan dengan korupsi. Kalau menghadapi teroris macam Amrozi, Imam Samodra, dan lain sebagainya, dengan sigap polisi bertindak. Kejaksaan pun, dengan proses yang sangat cepat, mampu menyeret para terdakwa ke hadapan hakim di persidangan. Tetapi, sama seperti politisi, ketika menangani kasus korupsi ada banyak alasan sehingga berkas perkara mesti bolak-balik dikembalikan ke polisi, bukti tidak mendukung, atau keluar SP3 (Surat Perintah Penghentian Penyidikian) kalau tidak dituntut bebas.

Macetnya hukum dalam penanganan kasus korupsi bisa dimengerti dengan melihat korupsi sebagai fenomena sosiologis. Dalam kacamata 
sosiologis, korupsi melibatkan jaringan elit kekuasaan, baik di eksekutif, legislatif maupun yudikatif.

\section{Fungsi, Peran, dan Kebijakan KPK Dalam Pencegahan dan Pemberantasan Korupsi}

KPK sebagai lembaga independen, artinya tidak ada intervensi dari pihak lain dalam penyelidikannya agar diperoleh hasil sebaik mungkin. KPK juga sebagai contoh sosial, dimana selama ini badan hukum kita masih mandul. Jika ada beberapa pejabat yang teriak-teriak karena ulah KPK, harus dipertanyakan kembali kepada para pejabat itu, berteriak karena takut ikut terseret ataukah kompensasi atas kesalahan sendiri? Dan perlu kita pertanyakan kembali mengapa berani teriak ketika kantong terisi uang kharam?

Peran KPK tidak hanya menindak koruptor di dalam negeri, tetapi juga membantu negara internasional memerangi korupsi, diantaranya membantu negara lain mengungkap skandal korupsi di negara tersebut. Peran KPK dalam pemberantasan penyuapan pejabat asing atau orang asing dalam bentuk mengungkap kasus yang ada di negaranya.

\section{Penyelidikan, Penyidikan, dan Penuntutan}

Segala kewenangan yang berkaitan dengan penyelidikan, penyidikan, dan penuntutan yang diatur dalam Undang-Undang Nomor 8 Tahun 1981 tentang Hukum Acara Pidana berlaku juga bagi penyelidik, penyidik, dan penuntut umum pada Komisi Pemberantasan Korupsi.

Penyelidikan, penyidikan, dan penuntutan tindak pidana korupsi dilakukan berdasarkan hukum acara pidana yang berlaku dan berdasarkan Undang-Undang Nomor 31 Tahun 1999 tentang Pemberantasan Tindak Pidana Korupsi.

Jadi, sebagaimana kita ketahui, bahwa pada mulanya keberadaan KPK sebagai lembaga pemberantasan korupsi yang dibentuk melalui Undangundang Nomor 30 Tahun 2002, karena lembaga pemerintah yang menangani tindak pidana korupsi dianggap belum berfungsi secara efektif dan efisien dalam pemberantasan tindak pidana korupsi, sangat diharapkan oleh masyarakat sebagai ujung tombak pemberantasan korupsi. Tetapi dalam perjalanannya kemudian, KPK dianggap tidak mampu melepaskan diri dari 
belenggu kepentingan penguasa, karena dianggap telah bertindak diskriminatif dalam memberantas korupsi, yaitu memberantas korupsi secara tebang pilih.

Dalam penjelasannya, KPK juga mendapat perlawanan dari para koruptor atau calon koruptor, antara lain melalui gugatan yudicial review ke Mahkamah Konstitusi. Bahkan ada pula upaya dari segelintir pihak yang mencoba mengurangi kewenangan KPK melalui perubahan undang-undang.

Masyarakat sangat mengharapkan KPK mampu memberantas korupsi di negeri ini. Hingga Juni 2007, KPK telah menerima 19.901 laporan dari masyarakat, dan 6.213 diantaranya berindikasi korupsi (Teten Masduki, Kompas 12/7/07). Tetapi tidak semua pengaduan itu bisa ditangani oleh KPK. Sebagai lembaga, KPK sangat kecil, karena hal itu sesuai dengan maksud dan tujuan pendiriannya. Dengan personel yang tidak sampai 100 orang, maka tidak mungkin KPK mampu menangani seluruh masyarakat.

Oleh karena itu perlu dilakukan pembaruan kebijakan KPK sebagai upaya pencegahan dan pemberantasan korupsi. Pembaruan kebijakan KPK itu harus dilakukan antara lain melalui hal-hal sebagai berikut :

a. KPK harus lebih menitikberatkan kebijakannya untuk memonitor penyelenggara pemerintahan

Artinya, sesuai dengan Pasal 6 huruf e, KPK harus lebih memfokuskan diri terhadap penyelenggara negara. Penyebabnya adalah terjadinya pergeseran trend korupsi, dari korupsi bersama-sama diantara pejabat daerah dengan DPRD atau dilingkungan DPRD, menjadi korupsi bersama antara penguasa (baik di daerah maupun di pusat) dengan pengusaha.

b. KPK harus lebih menitik beratkan tugasnya sebagai supervisi bukan substansi terhadap instansi yang berwenang untuk melakukan pemberantasan tindak pidana korupsi

Selama ini, KPK asyik "bermain" sendiri, dalam arti KPK dengan aparat penindak hanya 88 orang melakukan penyelidikan dan penyidikan sendiri terhadap semua laporan/pengaduan masyarakat. Akibatnya, tidak semua perkara bisa ditindak lanjuti karena keterbatasan tenaga. Hal inilah yang kemudian memunculkan tuduhan tebang pilih. Seharusnya KPK, setelah meneliti laporang/pengaduan 
masyarakat menyerahkan laporan/ pengaduan itu kepada Kejaksaan atau Kepolisian dengan ketentuan seluruh perkara yang diserahkan ini terus-menerus dimonitor oleh KPK sebagaimana diatur dalam Pasal 6 huruf b. Hanya terhadap laporan/ pengaduan yang sifatnya sangat signifikan dan dapat mengakibatkan kehancuran bangsa, KPK langsung turun sendiri untuk menindaknya. Kebijakan ini, sekaligus bisa dipergunakan untuk membersihkan aparat-aparat penegak hukum kotor yang menyimpang dari tugas yang diberikan oleh undangundang.

c. KPK tidak boleh hanya menunggu dan menerima laporan/pengaduan dari masyarakat saja

KPK disamping menerima laporan/pengaduan masyarakat selama 24 jam, harus aktif bertindak untuk melakukan penyelidikan tanpa harus menunggu adanya laporan/pengaduan terlebih dulu dari masyarakat.

d. KPK harus lebih aktif untuk melakukan sosialisasi pencegahan tindak pidana korupsi

KPK selama ini hanya menunggu dan bertindak setelah terjadinya tindak pidana korupsi. KPK kurang melakukan sosialisasi terhadap pencegahan terjadinya korupsi, maka seharusnya, tindakan pencegahan juga menjadi fokus utama KPK, dengan mengajak masyarakat turut serta secara aktif melakukan pencegahan korupsi.

e. Mengambil alih atau membuka kembali seluruh kasus-kasus korupsi yang sudah ditangani oleh instansi lain, tetapi tidak jelas kelanjutannya

Utamanya adalah terhadap kasus-kasus korupsi yang telah merugikan negara sangat besar, seperti kasus BLBI, dana Otsus Papua, atau bantuan kemanusiaan Aceh yang ditengarai telah dikorupsi.

Jadi jelas sekali bahwa KPK harus melakukan pembaruan dalam kebijakannya sebagai upaya untuk melakukan pencegahan dan pemberantasan korupsi. 


\section{PENUTUP}

\section{A. Kesimpulan}

Dapat disimpulkan bahwa korupsi merupakan penyelewengan atau penggelapan (uang negara atau perusahaan) dan sebagainya untuk keuntungan pribadi atau orang lain serta selalu mengandung unsur "penyelewengan" atau dishonest (ketidakjujuran). Dan korupsi akan berdampak pada masyarakat luas serta akan merugikan masyarakat umum dan negara. Di Indonesia, korupsi identik dengan tindakan buruk yang dilakukan oleh aparatur birokrasi serta orang-orang yang berkompeten dengan birokrasi. Korupsi dapat bersumber dari kelemahan-kelemahan yang terdapat pada sistem politik dan sistem administrasi negara dengan birokrasi sebagai perangkat pokoknya.

Penerapan hukum juga merupakan penyebab lain meluasnya korupsi. Seperti halnya delik-delik hukum yang lain, delik hukum yang menyangkut korupsi di Indonesia masih begitu rentan terhadap terhadap upaya pejabat-pejabat tertentu untuk membelokkan hukum menurut kepentingannya. Dalam relita di lapangan, banyak kasus untuk menangani tindak pidana korupsi yang sudah diperkarakan bahkan terdakwapun sudah divonis oleh hakim, tetapi selalu bebas dari hukuman ataupun mendapatkan hukuman yang tidak sesuai dengan pelanggarannya; contoh saja kasus Angelina Sondakh, seperti yang sudah dijelaskan diatas. Itulah sebabnya kalau hukuman yang diterapkan tidak drastis, upaya pemberantasan korupsi dapat dipastikan gagal.

\section{B. Saran}

Sikap untuk menghindari korupsi seharusnya ditanamkan sejak dini. Dan pencegahan korupsi dapat dimulai dari hal yang kecil. Dan seharusnya pemerintah lebih tegas terhadap terpidana korupsi.

Untuk meminimalisasi terhadinya tindak pidana korupsi di Indonesia, diperlukan adanya sistem pemidanaan yang dilakukan secara tegas terhadap pelaku tindak pidana korupsi di Indonesia, sehingga menimbulkan efek jera tanpa mengabaikan pembinaan bagi warga binaannya. Selain itu, para penegak hukum perlu ditingkatkan pengaturan mengenai pemberian remisi ke dalam suatu ketentuan hukum yang berkaitan dengan pemberian remisi. 
Perlu segera dilakukan pembaruan dalam kebijakan KPK untuk melakukan pencegahan dan pemberantasan korupsi. Pembaruan kebijakan itu, harus dilakukan dengan menyesuaikan tugas dan wewenang KPK dengan sumber daya yang dimiliki KPK. Jika tidak, dikhawatirkan nasib lembaga pemberantas korupsi ini (KPK), tidak akan berbeda jauh dengan lembaga-lembaga pemberantas korupsi pendahulunya yang pernah dibentuk pemerintah, yaitu dibubarkan.

\section{DAFTAR PUSTAKA}

\section{Buku}

Hamzah jur Andi (2005), Pemberantasan Korupsi, Jakarta, PT Raja Grafindo Persada.

\section{Website}

Anonim, Upaya Pemberantasan Korupsi, http/blogstoryaboutme.blogspot.com/ 2012/11/makalah-pemberantasan-korupsi-di.html, diakses tanggal 20 Oktober 2017.

http://www.facebook.com/notes/dukung-susno-duaji-untuk-kebenaran/ memberantaskorupsi-dengan-menerapkan-undang-undang-tentang-tindak-pidana-pencucianuang/134447996578689.

http://megahsholihah.33.blogspot.co.id/2015/07/peran-kpk-terhadap-pemberantasankorupsi.htm 